\title{
Spider community responds to litter complexity: insights from a small-scale experiment in an exotic pine stand
}

\author{
Luciana R. Podgaiski1 \& Gilberto G. Rodrigues²
}

\author{
1. Departamento de Ecologia, Universidade Federal do Rio Grande do Sul, Av. Bento Gonçalves, 9500, prédio 43422, sala 119, $91501-970$ Porto Alegre, RS, Brazil. \\ (podgaiski@gmail.com) \\ 2. Departamento de Zoologia, Universidade Federal de Pernambuco, Av. Prof. Moraes Rego, s/n, 50670-420 Recife, PE, Brazi
}

Received 3 April 2016.

Accepted 22 September 2016

DOI: $10.1590 / 1678-4766 e 2017007$

\begin{abstract}
Conservation of biodiversity in agroecosystems is an urgent need, and a suitable approach to maximize animal biodiversity and their services is the restoration of habitat heterogeneity. Here we investigated the value of increasing litter complexity in tree plantations of exotic pine for ground spiders. We hypothesized that increasing the litter complexity of these systems, as it would be the case in ecologically designed plantations, would increase spider aggregations. We performed a small-scale litter manipulation experiment within an exotic pine stand in the municipality of Minas do Leão, Rio Grande do Sul, Brazil, and compared spider diversity in simple (only pine needles) and complex substrates (with the addition of diverse native broadleaves). We found 1,110 spiders, 19 families and 32 morphospecies. The most abundant families were Linyphiidae, Theridiidae and Salticidade, and the dominant morphospecies were Thymoites sp. 2 and Lygarina sp. Web-building spiders represented $61 \%$ of total spider abundance, and 17 species, while hunting spiders, $49 \%$ and 15 species. As expected, densities of spider individuals and species from both web-building and hunting spiders were higher in complex litter substrate. Potential preys (Collembola) also responded positively to the treatment, and had influence of spider community patterns. Our results suggest that ensuring some degree of plant and litter diversity within pine stands (e.g. understory establishment) might foster spider aggregations and possibly help to conserve their diversity at local-scales.
\end{abstract}

KEYWORDS. Habitat complexity, habitat selection, species diversity, foraging strategy.

RESUMO. Comunidade de aranhas responde a complexidade da serapilheira: percepções de um experimento de pequena escala em um talhão de pinus exótico. A conservação da biodiversidade em agroecossistemas é uma necessidade urgente, e uma abordagem adequada a maximizar a biodiversidade animal e seus serviços é a restauração da heterogeneidade de habitats. Aqui nós investigamos o valor do aumento da complexidade da serapilheira em plantações exóticas de pinus para aranhas de solo. Nossa hipótese é que aumentando a complexidade da serapilheira nestes sistemas, como seria o caso em plantações com design ecológico, as agregações de aranhas aumentariam. Nós realizamos uma manipulação experimental de pequena escala em uma plantação exótica de pinus no município de Minas do Leão, Rio Grande do Sul, e comparamos a diversidade de aranhas em substrato simples (somente acículas de pinus) e complexo (com adição de folhas nativas diversas). Nós encontramos 1.110 aranhas, 19 famílias e 32 morfoespécies. As famílias mais abundantes foram Linyphiidae, Theridiidae e Salticidade, e as morfoespécies dominantes foram Thymoites sp. 2 e Lygarina sp. Aranhas de teia representaram $61 \%$ da abundância total de aranhas e 17 espécies, enquanto aranhas caçadoras, $49 \%$ e 15 espécies. Como esperado, densidades de indivíduos e de espécies de ambas construtoras de teia e caçadoras foram maiores em substrato complexo. Potenciais presas (Collembola) também responderam positivamente ao tratamento, e influenciaram os padrões das comunidades de aranhas. Nossos resultados sugerem que garantir algum grau de diversidade de plantas e serapilheira dentro de talhões de pinus (e.g. estabelecimento de sub-bosque) poderia promover agregações de aranhas e possivelmente ajudar a conservar sua diversidade em escalas locais.

PALAVRAS-CHAVE. Complexidade do hábitat, seleção de hábitat, diversidade de espécies, estratégia de forrageamento.

Spiders are predatory arthropods widely distributed across terrestrial ecosystems and agroecosystems (Отт et al., 2007; CoRCUERA et al., 2015; MARÍN et al., 2016; RicALDE et al., 2016), being largely influenced by prey availability and habitat structure (HaLAJ et al., 1998). Spiders can display a range of different foraging strategies (CARDOSO et al., 2011). Web-building (the ones that anchor prey-capture webs to the substrate) and hunting spiders (the ones actively pursuing or using a sit-and-wait strategy for prey capture, not using webs to trap prey) interact differently with habitat structure, but studies have revealed that the densities of both groups are commonly enhanced when habitat complexity increases (Langellotto \& Denno, 2004). Spiders can affect ecosystem functions through top-down effects on herbivores or decomposers, and their foraging strategies are key functional traits to explain such effects (LiU et al., 2015a). In general, they are considered beneficial to agroecosystems by controlling the abundance of various pest species (SUNDERLAND \& SAMU, 2000). Nevertheless, studies and management actions employing habitat structural modifications to promote predators are still rare but are beginning to arise (e.g. HALAJ et al., 2000; SCHMIDT-ENTLING \& DöBELI, 2009).

The conversion of natural complex ecosystems to 
simplified agroecosystems markedly decline diversity across many taxa (e.g. FLYNN et al., 2009). A valuable approach to maximize animal biodiversity and their mediated ecosystem services in agricultural landscapes is the restoration of habitat complexity, which is relevant from large spatial scales (e.g. across a gradient of different fields) to more local-scales (e.g. within a specific field) (BENTON et al., 2003, ScHMIDT et al., 2005). Heterogeneous habitats may present a larger variety of ecological niches to be exploited in comparison to simplified habitats, fostering possibilities of more species coexistence with a greater use of resources (FINKE \& SNYDER, 2008). Plant diversity is one of the primary determinants of habitat complexity, and studies have shown that increasing the diversity of native plants in agroecosystems helps to conserve animal species (e.g. SMITH et al., 2008; BENNETT \& Gratton, 2013).

Among agroecosystems, plantation forests are widespread all around the globe, not respecting biome characteristics neither native biodiversity. The majority of plantation forests, inclusive mega diverse countries as Brazil, still comprise intensively managed monocultures of exotic trees (e.g. Eucalyptus, Acacia and Pinus; PAQuetTE \& Messier, 2010). Empirical evidence has demonstrated that industrial forests may achieve economic purposes while maintaining considerable habitat complexity and conserving a large fraction of the natural forest biodiversity, including both within- and between stand diversity. There are several recommendations to ecologically design tree plantations; some few examples are (1) planting trees in lower densities and allowing natural rich understory establishment and development (FonsECA et al., 2009), (2) leaving natural vegetation margins and patches among the rows of planted trees, and (3) using native mixed-species, or polycultures (Paquette \& Messier, 2010). As these designs allow greater plant diversity, they potentially increase the leaf-litter layer complexity within the plantations. However, the challenge of shaping agricultural landscapes to meet joint production and conservation goals requires an increase in the economic and ecological research efforts (SCHERR \& MCNEELY, 2008).

Here we focus on ground spider communities to explore the role of litter layer complexity on plantation forests. We performed a small-scale experiment (patch scale) within an exotic pine stand in southern Brazil (Rio Grande do Sul). Pure pine stands (Pinus) present a very simplified litter layer in terms of habitat structure for invertebrates due to the accumulation of a homogeneous needle-like substrate in the soil when compared to native ecosystems or broadleaved tree plantations. We hypothesized that increasing the litter complexity of these systems, as it would be the case in ecologically designed plantations where plant diversity is greater, would benefit spider communities (i.e. increase their aggregation in more complex litter, LANGELLOTTO \& DENNO, 2004). In order to test this hypothesis, we created two levels of substrate complexity in replicated plots: (1) simple, formed only by pine needles, and (2) complex, with the addition of diverse native broadleaves to the pine forest floor. We tested how densities of individuals and species of spiders responded to the treatments taking into account major foraging strategies.

Besides several studies have investigated the relation of ground spiders to habitat features and complexity in different agroecosystems (e.g. Schmidt et al., 2005; CORCUERA et al., 2015; MARín et al., 2016), to our knowledge there are no published studies addressing such topic in Brazil, particularly regarding to pine plantations. Specifically in South Brazil, some attempts were done in order to compare spider diversity patterns between agroecosystems and adjacent native ecosystems, such as the studies of BALDISSERA et al. (2008) in tree plantations, including pine, and native Araucaria forest, RoDrigues et al. (2009) in rice field, grassland and native forest, and RoDRIGUES et al. (2010) in Eucalyptus plantations and natural grasslands. Other studies in agroecosystems in South Brazil describe spider assemblages, for example, in olive groves (RICALDE et al., 2016), corn plantations (DA SILVA et al., 2014), citrus groves (Отт et al., 2007) and irrigated rice (RoDRIGUES et al., 2008). Here we also expect to contribute with a very first view of the ground spider assemblages inhabiting pine plantations in the state of Rio Grande do Sul.

\section{MATERIALS AND METHODS}

Study area. A slash pine stand of Pinus elliottii Engelm (Pinaceae) settled in an intensively managed landscape in Southern Brazil was chosen as the model system to perform the experiment. In December 2007 we established the experiment in an area of approximately 20 ha in the municipality of Minas do Leão, Rio Grande do Sul, Brazil (3009'44.2”S; 5200'17.2”W). The landscape is characterized by a mosaic of coal mining activities and tree plantations (especially Pinus); native natural forests and grasslands are scarce or inexistent in a $10 \mathrm{~km}$ radius from the study site. Coal was exploited by opencast mining from the study site around the year 1980 and during 2001-2002, and the open cave was filled with remaining soil, coal wastes and coal combustion residues. Whereas vegetated with grasses, pine seeds from neighbor stands reached the land, quickly establishing a monospecific ecosystem. Pinus elliottii is native to the southeast United States and widely planted in Brazil. Plants from this genus are extremely invasive, advancing in deforested areas and natural ecosystems in South America (SimBerLoff et al., 2012). The climate of the study site is temperate, with precipitation well distributed throughout the seasons ( $C f a$ type according to the KöppenGeigen climate classification, PEeL et al., 2007).

Experimental design. We performed the experiment using a randomized block design. This design is efficient to control for spatial and temporal heterogeneity (e.g. patchy habitats and different sampling time), assuming that environmental conditions and biological communities are more similar within than between blocks, which is suitable to clearly detect the treatment effects of interest (GOTTELLI \& ELLISON, 2013). Eight blocks were placed systematically within the study area with a minimum distance of $100 \mathrm{~m}$. 
Each block was composed by two experimental units of 90 x $60 \mathrm{~cm}$ distant $2 \mathrm{~m}$ from each other, assigned randomly to treatments.

We had two treatments per block: (1) simple and (2) complex substrate. Each treatment in each block received approx. $360 \mathrm{~g}$ of oven-dried leaves $\left(60^{\circ} \mathrm{C} ; 72 \mathrm{~h}\right)$ over the natural litter layer. The leaves were enclosure in nine nylon bags (30 x $20 \mathrm{~cm} ; 20 \mathrm{~mm}$ mesh size; $40 \mathrm{~g}$ of dry mass) per experimental unit. The simple substrate was composed exclusively by bags enclosing pine needles, and the complex substrate presented bags with pine needles and also with native broadleaves in different architectures to generate habitat heterogeneity. Details regarding the characteristics of the bags, native plant species used and other differences between treatments are found in Table I.

At two sampling occasions (after 3 and 6 months) we randomly selected four blocks, collected all bags, and brought them to the laboratory. Spiders and other invertebrates that colonized the litter were immediately extracted by hand, and using modified Berlese-Tüllgren funnels during one week. We classified all the spiders in families and, based on family affiliation, in two different major foraging strategies: webbuilding (the ones that must anchor their hunting webs to the substrate) and hunting predators (the ones that actively pursue or use a sit-and-wait strategy for prey capture, not using webs to trap prey). To classify the groups, we checked DiAs et al. (2010) and CARDoso et al. (2011).

The adult spiders were determined in morphospecies, and deposited in Museu de Ciências Naturais (MCN) of the Fundação Zoobotânica do Rio Grande do Sul (FZBRS), Porto Alegre, RS, Brazil. Other invertebrates were classified in orders. Among them, we considered Collembola as a potential spider prey group (e.g. LIU et al., 2015b). The remaining litter mass per experimental unit after 3 (four blocks) and 6 months (four blocks) was estimated after oven-drying the substrate from the bags $\left(60^{\circ} \mathrm{C} ; 72 \mathrm{~h}\right)$.

Data analyses. We evaluated the effects of habitat complexity on spiders by comparing their colonization patterns in the different substrate treatments. For that, we tested for differences in spider abundance and spider richness for both web-builders and hunters between substrate type using ANOVA in blocks, and considering the abundance of potential preys (Collembola) as covariate. Previously to the analyses, spider abundance and richness were standardized by a density measure in each experimental unit (individuals. $\mathrm{g}^{-1}$ of dry litter, and species. $\mathrm{g}^{-1}$ of dry litter respectively). The same standardization was performed to Collembola abundance. In addition, we also evaluated effects of substrate type on Collembola densities with ANOVA in blocks.

As species richness is very sensitive to the number of individuals sampled, we used individual-based rarefaction (interpolation) and extrapolation curves with 95\% unconditional confidence intervals (COLWELL et al., 2012) to compare total spider richness between treatments. We did not test direct time effects on spider colonization of the treatments, which was statistically controlled by the block design, and neither treatment effects on species composition. Due to the small scale of our experiment we are assuming that spiders colonizing the treatments came directly from the studied site. We carried out linear models in $\mathrm{R}$ version 3.0.2 (R Development Core Team, 2014), and interpolation (rarefaction) and extrapolation curves with INEXT online (HsieH et al., 2013).

Tab. I. Comparison between the substrate treatments (simple x complex) evaluated in the experiment in a pine stand in Minas do Leão, Southern Brazil.

\begin{tabular}{lc}
\hline Substrate treatment & Simple \\
\hline Number of experimental units & 8 \\
Number of bags per experimental unit & 9 \\
Number of leaf species & 1 \\
Leaf species identity & P. elliottii \\
& \\
Type of bags & Only single bags \\
& \\
\hline Bag arrangement & \\
& Rectangle shape 3 \\
& x 3 bags over the \\
natural litter layer.
\end{tabular}

Initial mass of each bag $(\mathrm{g})$

Initial mass of each experimental unit (g)

Average remaining mass and standard error in experimental units (g)

Average abundance and standard error of Collembola (individuals. $\mathrm{g}^{-1}$ of dry litter)

\section{natural litter layer.}

\section{0}

360

$262.8 \pm 8.67$

$2.66 \pm 1.53$
Complex

8

9

5

P. elliottii

Inga marginata

Cupania vernalis

Luehea divaricata

Schinus terebinthifolius

5 single bags: one of each species 4 mixed bags: $25 \%$ (by volume) of each broadleaf species

Rectangle shape $3 \times 3$ bags over the natural litter layer. The pine bag was settled in the middle, surrounded by the bags with broadleaves (intercalating single and mixed bags)

40

360

$200.8 \pm 6.33$ 


\section{RESULTS}

We found a total of 1,110 litter spiders from 19 families in the pine plantation. The most abundant families were Linyphiidae (27.6\% of the total abundance), Theridiidae (23.2\%), Salticidade (17.5\%), Hahniidae (9\%), and Oonopidae $(6 \%)$. This pattern of dominance was found in both substrate types. Only $38 \%$ of the number of individuals was represented by adults, which were identified in 32 morphospecies (Tab. II). Linyphiidae was the richest family (11 species). The dominant species were Thymoites sp. 2 (25.2\%, Theridiidae), Lygarina sp. (23\%, Linyphiidae), Oonopinae sp. (10.2\%, Oonopidae), Hahniidae sp.1 (10\%, Hanniidae), Orthobula sp.1 (7.3\%, Phrurolithidae) and Neomaso damocles Miller, 2007 (5.9\%, Linyphiidae). Thymoites sp. 2 and Orthobula sp.1 were the only species recorded in all experimental blocks. Twenty morphospecies were found exclusively in complex litter patches $(80 \%$ of the total number of hunting spiders and $47 \%$ of the total number of web-building species, Tab. II). Three species were exclusive from pine litter patches, although one of them is a pantropical synanthropic species (Oecobius navus Blackwall, 1859, Oecobidae).
Web-building strategy presented 676 individuals (61\% of total spider abundance), 6 families and 17 species. Hunting spiders summed 434 individuals (49\%), 13 families and 15 species. Complex litter substrate sheltered more densities of individuals and species of both web-building and hunting spiders (Table III, Fig. 1). Potential preys (Collembola) were also important to explain the spider community patterns (Table III), also being responsive to substrate type ( $\mathrm{F}^{1}$, $7=25.14, \mathrm{P}=0.006$, Table I).

In average, there were 13.9 spider individuals and 2.2 morphospecies in each $100 \mathrm{~g}$ of dry simple substrate and 54.3 individuals and 5.7 morphospecies in each 100 $\mathrm{g}$ of dry complex substrate. This means that the density of individuals and morphospecies was respectively $74.3 \%$ and $38.2 \%$ higher in complex substrate. Interpolation (rarefaction) and extrapolation curves with $95 \%$ confidence intervals showed that the increase in spider richness was not an artifact of their increase in abundance (Fig. 2).

\section{DISCUSSION}

We experimentally investigated the role of litter layer complexity to ground spiders in an exotic pine stand

Tab. II. Spider community composition (adults only) sampled in simple and complex substrate treatments in a pine stand in Minas do Leão, Southern Brazil. Abundance values represent eight experimental units of each treatment.

\begin{tabular}{|c|c|c|c|c|}
\hline Family & Morphospecies & Simple & Complex & Total \\
\hline \multicolumn{5}{|l|}{ Hunting spiders } \\
\hline Caponiidae & Nops meridionalis Keyserling, 1891 & 0 & 10 & 10 \\
\hline Ctenidae & Isoctenus $\mathrm{sp}$. & 0 & 1 & 1 \\
\hline \multirow[t]{2}{*}{ Gnaphosidae } & Apopyllus silvestrii (Simon, 1905) & 0 & 1 & 1 \\
\hline & Gnaphosidae sp. & 0 & 1 & 1 \\
\hline Oonopidae & Oonopinae sp. & 2 & 41 & 43 \\
\hline \multirow[t]{4}{*}{ Phrurolithidae } & Orthobula sp. 1 & 3 & 28 & 31 \\
\hline & Orthobula sp. 2 & 0 & 1 & 1 \\
\hline & Orthobula sp. 3 & 0 & 1 & 1 \\
\hline & Orthobula sp. 4 & 0 & 1 & 1 \\
\hline \multirow[t]{5}{*}{ Salticidae } & Aphirape sp. & 0 & 1 & 1 \\
\hline & Breda sp. & 0 & 3 & 3 \\
\hline & Salticidae sp. 1 & 0 & 3 & 3 \\
\hline & Salticidae sp. 2 & 0 & 1 & 1 \\
\hline & Unidentatae sp. & 1 & 0 & 1 \\
\hline Trachelidae & Meriola mauryi Platnick \& Ewing, 1995 & 0 & 5 & 5 \\
\hline \multicolumn{5}{|c|}{ Web-building spiders } \\
\hline \multirow[t]{2}{*}{ Hahniidae } & Hahniidae sp. 1 & 10 & 32 & 42 \\
\hline & Hahniidae sp. 2 & 0 & 1 & 1 \\
\hline \multirow[t]{11}{*}{ Linyphiidae } & Erigone sp. & 0 & 2 & 2 \\
\hline & Gigapassus octarine Miller, 2007 & 0 & 6 & 6 \\
\hline & Lygarina sp. & 42 & 55 & 97 \\
\hline & Mermessus sp. & 0 & 1 & 1 \\
\hline & Neomaso arundicola Millidge, 1991 & 0 & 1 & 1 \\
\hline & Neomaso damocles Miller, 2007 & 10 & 15 & 25 \\
\hline & Neomaso sp. 1 & 0 & 1 & 1 \\
\hline & Neomaso sp. 2 & 1 & 0 & 1 \\
\hline & Scolecura cambara Rodrigues, 2005 & 5 & 2 & 7 \\
\hline & Smermisia vicosana (Bishop \& Crosby, 1938) & 7 & 5 & 12 \\
\hline & Sphecozone sp. & 1 & 6 & 7 \\
\hline Mysmenidae & Itapua sp. & 0 & 2 & 2 \\
\hline Oecobidae & Oecobius navus Blackwall, 1859 & 1 & 0 & 1 \\
\hline \multirow[t]{2}{*}{ Theridiidae } & Thymoites sp. 1 & 0 & 5 & 5 \\
\hline & Thymoites sp. 2 & 46 & 60 & 106 \\
\hline \multicolumn{2}{|c|}{ Total abundance of adult spiders } & 129 & 292 & 421 \\
\hline \multicolumn{2}{|c|}{ Total morphospecies richness } & 12 & 29 & 32 \\
\hline
\end{tabular}




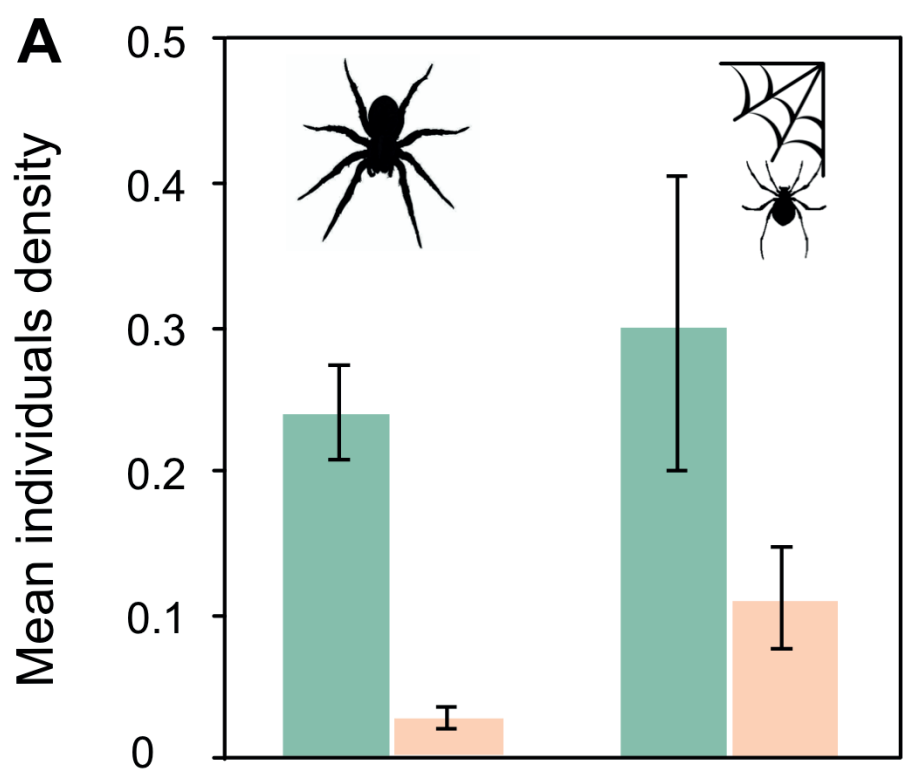

\section{Substrate} Complex

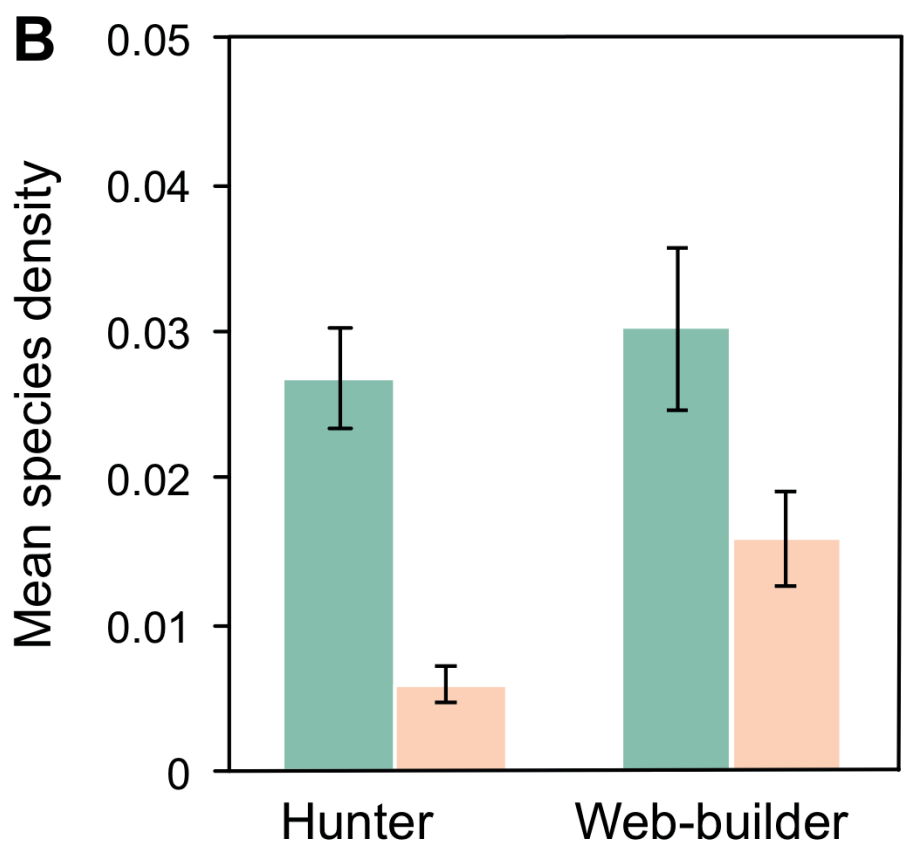

Fig. 1. Mean density of individuals (A, individuals. ${ }^{-1}$ of dry litter) and morphospecies (B, species. $\mathrm{g}^{-1}$ of dry litter adults only) \pm standard error of hunting and web-building spiders in simple and complex substrate treatments in a pine stand in Minas do Leão, Southern Brazil.

settled in South Brazil. The spider community colonizing our experiment from this stand was mostly represented by spiders displaying web-building strategy, more specifically space web weavers (Linyphiidae and Theridiidae; DiAs et al., 2012), and by ground hunters (Salticidae) in a little diminished proportion. Analogous pattern regarding these dominant ground families was also registered in DA SILVA et al. (2014) for corn plantations, and RODRIGUEs et al. (2010) for Eucalyptus plantations in Rio Grande do Sul. In this former study, similarly to our results, a species of Thymoites (Linyphiidae) was also found to be very abundant in the leaflitter, being frequent in all sampled sites. The spider richness registered here for the pine plantation (32 morphospecies) is comparable to the richness found in these previous mentioned works (corn plantation= 27; Eucalyptus plantations=35) and also to the forest floor of a native restinga forest nearby (44 morphospecies; RODRIGUES, 2005). A lack of published surveys on soil araneofauna makes difficult any further discussions about spider diversity in the study region.

Based in one of the cornerstones of ecology ('the habitat heterogeneity hypothesis', e.g. Tews et al., 2004), enhancing the complexity of agricultural systems from within individual fields to whole landscapes has been pointed out as a useful approach to ensure animal diversity (BENTON $e t$ 


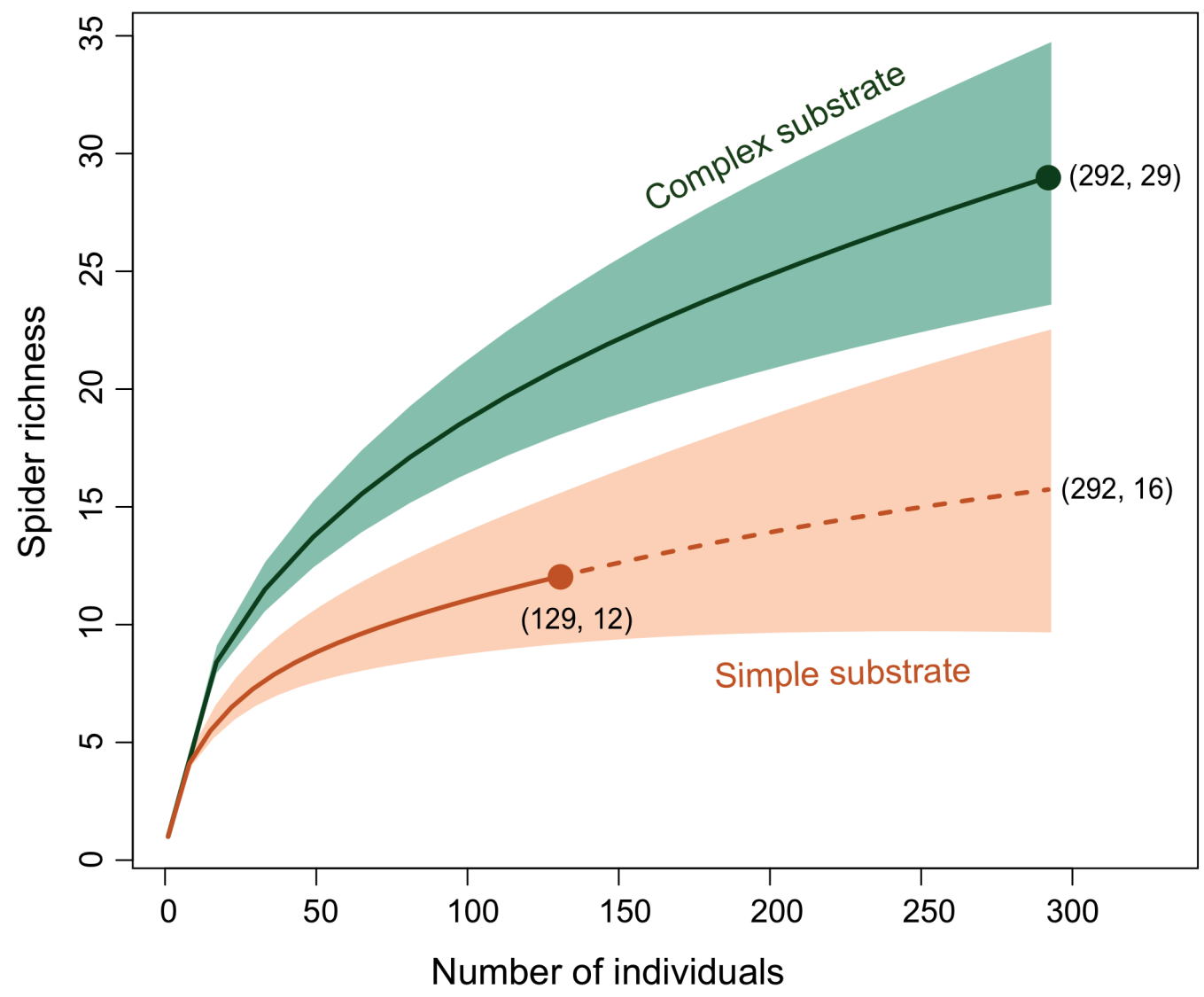

Fig. 2. Individual-based rarefaction (interpolation, solid lines) and extrapolation (dashed line) from eight experimental units (90 x $60 \mathrm{~cm})$ of simple and complex substrate in a pine stand in Minas do Leão, Southern Brazil, under multinomial model, with $95 \%$ unconditional confidence intervals (shaded area, bootstrap with 1,000 replications) (based on Colwell et al. 2012). In parenthesis, the number of individuals and morphospecies observed and estimated (extrapolation) respectively in each treatment.

Tab. III. F and P-values (in brackets) from analysis of variance for abundance and species richness of hunting and web-building spiders sampled in a pine stand in Minas do Leão, Southern Brazil. Sources of variation are substrate type (simple or complex), abundance of potential prey, and blocks ( $\mathrm{n}=8$ ). Abundance and richness were standardized by density measures (individuals. $\mathrm{g}^{-1}$ of dry litter, and species. $\mathrm{g}^{-1}$ of dry litter).

\begin{tabular}{llccc}
\hline \multirow{2}{*}{ Response variables } & & Substrate type $(\mathrm{df}=1,6)$ & Potential prey $(\mathrm{df}=1,6)$ & Block $(\mathrm{df}=7,6)$ \\
\hline \multirow{2}{*}{ Abundance } & Hunter & $59.22(<\mathbf{0 . 0 0 1})$ & $12.34(\mathbf{0 . 0 1 2})$ & $0.44(0.846)$ \\
& Web-builder & $5.83 \mathbf{( 0 . 0 5 2 )}$ & $14.90 \mathbf{( 0 . 0 0 8 )}$ & $0.82(0.603)$ \\
\multirow{2}{*}{ Richness } & Hunter & $29.96 \mathbf{( 0 . 0 0 1 )}$ & $0.27(0.620)$ & $0.90(0.558)$ \\
& Web-builder & $17.45 \mathbf{( 0 . 0 0 6 )}$ & $36.19(\mathbf{0 . 0 0 1})$ & $1.15(0.441)$ \\
\hline
\end{tabular}

al., 2003; SCHERR \& MCNEELY, 2008). Our study supports such approach, and has experimentally shown in a patch scale that the substrate complexity within a very simplified system has a considerable influence on spider communities by aggregating more individuals and species. Web-building and hunting spiders had their diversities enhanced in complex patches formed by the addition of different types of leaves to the pine forest floor. The mechanisms behind such results in this system need further understanding, but they are possible related to: favorable structural proprieties, prey availability, and refugees from predation (see review in LANGELLOTTO \& DENNO, 2004).
Broadleaves clearly present more habitat space than pure pine needles. The spaces within curled leaves, the underside of twisted leaves and the gaps between leaves with different sizes represent an improvement in microsites for foraging, reproduction and suitable microclimate (UETZ, 1974; WAGNER et al., 2003). Web-building spiders rely on proper substrates to attach their webs (SAMU et al., 1996); hence structured habitats provide more attachment sites than simple habitats. The complex litter patches that we created in the pine plantation could have supported improved aggregation of spiders due to more favorable structural proprieties than the pine litter. 
Spiders are good at finding prey-rich patches (WISE, 1993). Both web-building and hunting spiders, which do not depend directly on habitat structure for foraging, may have benefited in complex patches because they encountered more abundant prey there. In complex structured habitats, prey location and capture could be more effective due to the increase in detection of substrate-born vibrations (Langelotto \& Denno, 2006). Collembolans, and also many other macrofaunal groups as woodlice, beetles and small cockroaches (not showed here), were more abundant in complex litter patches. We indeed found a significant relationship between collembolan and spider densities. CHEN \& Wise (1999), and HalaJ \& Wise (2002) experimentally enhanced the resource base (detritus-addition) in forests of USA, and have found 2-4 times higher densities of collembolans and associated spiders than in controls. These results reveal substantial bottom-up effects propagating through the decomposition food web, which can also potentially explain our results (e.g. high quality resources elevated populations of detritivores, which reduced food limitation of predators and caused their densities to increase).

Further, as generalist predators that often prey on one another, spiders also may found proper spatial refuges from agonistic interactions in complex substrate, thereby reducing detectability, enhancing ability to scape and facilitating coexistence (FINKE \& DENNO, 2002; JANSSEN et al., 2007). Spiders tend to remain in habitats where conditions are optimal (SundERLAND \& SAMU, 2000). Patches with complex substrate possibly received high immigrations associated with reduced emigration rates during the course of the experiment, as suggested by LANGellotTo \& DenNo (2004). Because of the small spatial scale evaluated here, it is expected that the immigrating species have come directly from the studied pine stand (i.e. not from other adjacent ecosystems) with individuals constantly moving around in search of suitable sites.

From an applied perspective, the results from this litter manipulation experiment suggest that integrating elements of habitat complexity in pine plantations, i.e. ensuring some degree of plant diversity to maintain a complex litter layer, might enhance spider aggregations. Allowing native understory establishment within the stand, or using polycultures (FonseCA et al., 2009; PAQUETTE \& MESSIER, 2010) are some examples of strategies that could be used to benefit generalist predators biodiversity and their mediated ecosystem services. The mixing of species stands comprising two or more tree commercial species is a strategy increasingly being considered to achieve ecological and economic goals in Europe (e.g. CAVARD et al., 2011). However, a few recent studies have demonstrated that mixed stands of pine and oak trees showed no influence on grounddwelling spider diversity when compared to single species stands (OXBrough et al., 2012; BARSOum et al., 2014). Smallscale experimental approaches, like ours, provide important insights in ecological hypothesis testing under controlled situations. But the ecological design of tree plantations in order to support forest biodiversity require a lot of further research integrating different taxa and trophic levels at larger spatial scales.

Acknowledgements. We are indebted to Maria A.L. Marques, Erica H. Buckup and Everton N.L. Rodrigues for helping in spider identifications, to Companhia Riograndense de Mineração for allowing access to the study site, to Ricardo Ott for lending Winkler extractors, which were adapted to modified Berlese-Tüllgren funnels for this study, and to Fernanda S. Silveira for helping in the lab work. Luciana R. Podgaiski received Master scholarship from CAPES (Brazil).

\section{REFERENCES}

Baldissera, R.; Ganade, G.; Brescovit, A. D. \& Hartz, S. M. 2008. Landscape mosaic of Araucaria forest and forest monocultures influencing understorey spider assemblages in southern Brazil. Austral Ecology 33:45-54.

Barsoum, N.; Ashwood, F.; Reed, K.; Bonnet-Lebrun, A. S. \& Leung, F. 2014. Ground-dwelling spider (Araneae) and carabid beetle (Coleoptera: Carabidae) community assemblages in mixed and monoculture stands of oak (Quercus robur L./Quercus petraea (Matt.) Liebl.) and Scots pine (Pinus sylvestris L.). Forest Ecology and Management 321:29-41.

Bennett, A. B. \& Gratton, C. 2013. Floral diversity increases beneficial arthropod richness and decreases variability in arthropod community composition Ecological Applications 23:86-95.

Benton, T. G.; Vickery, J. A. \& Wilson, J. D. 2003. Farmland biodiversity: is habitat heterogeneity the key? Trends in Ecology and Evolution 18:182-188.

Cardoso, P.; Pekár, S.; Jocqué, R. \& Coddington, J. A. 2011. Global patterns of guild composition and functional diversity of spiders. PLOS ONE 6:e21710.

Cavard, X.; Macdonald, S. E.; Bergeron, Y. \& Chen, H. Y. H. 2011. Importance of mixed woods for biodiversity conservation: evidence for understory plants, songbirds, soil fauna, and ectomycorrhizae in northern forests. Environmental Reviews 19:142-161.

CHEN, B. \& Wise, D. H. 1999. Bottom-up limitation of predaceous arthropods in a detritus-based terrestrial food web. Ecology 80:761-772.

Colwell, R. K.; Chao, A.; Gotelli, N. J.; Lin, S.; Mao, C. X.; Chazdon, R. L. \& Longino, J. T. 2012. Models and estimators linking individualbased and sample-based rarefaction, extrapolation and comparison of assemblages. Journal of Plant Ecology 5:3-21.

Corcuera, P.; Valverde, P. L.; Jiménez, M. L.; Ponce-Mendoza, A.; De LA RosA, G. \& Nieto, G. 2015. Ground spider guilds and functional diversity in native pine woodlands and Eucalyptus plantations. Environmental Entomology 45:292-300.

Da Silva, L. V.; Ribeiro, A. L. P. \& Lúcio, A. D. 2014. Diversidade de aranhas de solo em cultivos de milho (Zea mays). Semina: Ciências Agrárias 35:2395-2404.

Dias, S. C.; Carvalho, L. S.; Bonaldo, A. B. \& Brescovit, A. D. 2010. Refining the establishment of guilds in Neotropical spiders (Arachnida: Araneae). Journal of Natural History 44:219-239.

FINKE, D. L. \& SNYDER, W. E. 2008. Niche partitioning increases resource exploitation by diverse communities. Science 321:1488-1490.

Finke, D. L. \& Denno, R. F. 2002. Intraguild predation diminished in complex structured vegetation: implications for prey suppression. Ecology 83:643-652.

Fonseca, C. R.; Ganade, G.; Baldissera, R.; Becker, F. G.; Boelter, C. R.; Brescovit, A. D.; Campos, L. M.; Fleck, T.; Fonseca, V. S.; Hartz, S. M.; Joner, F.; KäFfer, M. I.; Leal-Zanchet, A. M.; Marcelli, M. P.; Mesquita, A. S.; Mondin, C. A.; Paz, C. P.; Petry, M. V.; Piovensan, F. N.; Putzke, J.; Stranz, A.; Vergara, M. \& VIEIRA, E. 2009. Towards an ecologically-sustainable forestry in the Atlantic Forest. Biological Conservation 142:1209-1219.

Flynn, D. F.; Godol-Prokurat, M.; Nogeire, T.; Molinari, N.; Richers, B. T.; Lin, B. B.; Simpson, N.; Mayfield, M. M. \& DeclercK, F. 2009. Loss of functional diversity under land use intensification across multiple taxa. Ecology Letters 12:22-33.

Gotelli, N. J. \& Ellison, A. M. 2013. A Primer of Ecological Statistics. Sunderland, Sinauer Associates Inc. 614p 
Halaj, J.; Cady, A. B. \& Uetz, G. W. 2000. Modular habitat refugia enhance generalist predators and lower plant damage in soybeans. Environmental Entomology 29:383-393.

Halaj, J.; Darrell, W. R. \& Moldenkel, A. R. 1998. Habitat structure and prey availability as predictors of the abundance and community organization of spiders in western Oregon forest canopies. Journal of Arachnology 26:203-220.

Halaj, J. \& Wise, D. H. 2002. Impact of a detrital subsidy on trophic cascades in a terrestrial grazing food web. Ecology 83:3141-3151.

HsieH, T. C.; MA, K. H. \& CHAO, A. 2013. iNEXT online: interpolation and extrapolation (Version 1.0) [Software]. Available at $<\mathrm{http}: / /$ chao. stat.nthu.edu.tw/blog/software-download/>.

Janssen, A.; Sabelis, M. W.; Magalhães, S.; Montserrat, M. \& Van Der Hammen, T. 2007. Habitat structure affects intraguild predation. Ecology 88:2713-2719.

Langellotto, G. A. \& Denno, R. F. 2004. Responses of invertebrate natural enemies to complex-structured habitats: a meta-analytical synthesis. Oecologia 139:1-10.

Langellotto, G. \& Denno, R. F. 2006. Refuge from cannibalism in complex structured habitats: implications for the accumulation of invertebrate predators. Ecological Entomology 31:575-581.

Liu, S.; Li, Z.; Sui, Y.; Schaefer, D. A.; Alele, P. O.; Chen, J. \& Yang, X. 2015a. Spider foraging strategies dominate pest suppression in organic tea plantations. BioControl 60:839-847.

Liu, S.; Chen, J.; Gan, W.; Schaefer, D.; Gan, J. \& Yang, X. 2015 b. Spider foraging strategy affects trophic cascades under natural and drought conditions. Scientific Reports 5:12396.

Marín, L.; Philpott, S. M.; De la Mora, A.; NúÑez, G. I.; Tryban, S. \& Perfecto, I. 2016. Response of ground spiders to local and landscape factors in a Mexican coffee landscape. Agriculture, Ecosystems and Environment 222:80-92.

Otт, A. P.; Отт, R. \& WolfF, V. R. S. 2007. Araneofauna de pomares de laranja Valência nos Vales do Caí e Taquari, Rio Grande do Sul, Brasil. Iheringia, Série Zoologia 97:321-327.

Oxbrough, A.; French, V.; Irwin, S.; Kelly, T. C.; Smiddy, P. \& O'Halloran, J. 2012. Can mixed species stands enhance arthropod diversity in plantation forests? Forest Ecology and Management 270:11-18

Paquette, A. \& Messier, C. 2010. The role of plantations in managing the world's forests in the Anthropocene. Frontiers in Ecology and the Environment 8:27-34

Peel, M. C.; Finlayson, B. L. \& MCMahon, T. A. 2007. Updated world map of the Köppen-Geiger climate classification. Hydrology and Earth System Sciences 11:1633-1644.

R Core TEam. 2014. R: A language and environment for statistical computing. R Foundation for Statistical Computing, Vienna, Austria. Available at $<$ http://www.R-project.org/>.

Ricalde, M. P.; Brescovit, A. D.; Nava, D. E.; Loeck, A. E.; Bisognin, A. \& Garcia, F. R. M. 2016. Spider assemblages in olive groves in Southern of Brazil. Bioagro 28:125-130.

Rodrigues, E. N. L. 2005. Araneofauna de serapilheira de duas áreas de uma mata de restinga no município de Capão do Leão, Rio Grande do Sul, Brasil. Biotemas 18:73-92.

Rodrigues, E. N. L.; MendonçA, JR. M. S. \& Ott, R. 2008. Fauna de aranhas (Arachnida, Araneae) em diferentes estágios do cultivo do arroz irrigado em Cachoeirinha, RS, Brasil. Iheringia, Série Zoologia 98:362-371.

Rodrigues, E. N. L.; MendonçA, JR., M. S. \& OtT, R. 2009. Spider diversity in a rice agroecosystem and adjacent areas in southern Brazil. Revista Colombiana de Entomología 35:89-97.

Rodrigues, E. N. L., Mendonça, Jr., M. S.; Rosado, J. L. O. \& Loeck, A. E. 2010. Soil spiders in differing environments: Eucalyptus plantations and grasslands in the Pampa biome, southern Brazil. Revista Colombiana de Entomología 36:277-284.

Samu, F.; Sunderland, K. D.; Topping, C. J. \& Fenlon, J. S. 1996. A spider population in flux: selection and abandonment of artificial websites and the importance of intraspecific interactions in Lepthyphantes tenuis (Araneae: Linyphiidae) in wheat. Oecologia 106:228-239.

SCherR, S. J. \& MCNeELY, J. A. 2008. Biodiversity conservation and agricultural sustainability: towards a new paradigm of 'ecoagriculture' landscapes. Philosophical Transactions of the Royal Society B 363:477-494

Schmidt, M. H.; Roschewitz, I.; Thies, C. \& Tscharntke, T. 2005 Differential effects of landscape and management on diversity and density of ground-dwelling farmland spiders. Journal of Applied Ecology 42:281-287.

Schmidt-Entling, M. H. \& DöBeli, J. 2009. Sown wildflower areas to enhance spiders in arable fields. Agriculture, Ecosystems and Environment 133:19-22.

Simberloff, D.; Nuñez, M. A.; Ledgard, N. J.; Pauchard, A.; Richardson, D. M.; Sarasola, M.; Van Wilgen, B. W.; Zalba, S. M.; Zenni, R. D.; Bustamante, R.; Peña, E. \& Ziller, S. R. 2012. Spread and impact of introduced conifers in South America: Lessons from other southern hemisphere regions. Austral Ecology 35:489-504.

Smith, J.; Potts, S. \& EgGleton, P. 2008. The value of sown grass margins for enhancing soil macrofaunal biodiversity in arable systems. Agriculture, Ecosystem, and Environment 127:119-125.

Sunderland, K. \& SAmU, F. 2000. Effects of agricultural diversification on the abundance, distribution, and pest control potential of spiders: a review. Entomologia Experimentalis et Applicata 95:1-13.

Tews, J.; Brose, U.; Grimm, V.; Tielbörger, K.; Wichmann, M. C.; SchwaGer, M. \& JeLtSCH, F. 2004. Animal species diversity driven by habitat heterogeneity/diversity: the importance of keystone structures. Journal of Biogeography 31:79-92.

Uetz, G. W. 1974. A method for measuring habitat space in studies of hardwood forest litter arthropods. Environmental Entomology 3:313315.

Wagner, J. D.; TOFT, S. \& Wise, D. H. 2003. Spatial stratification in litter depth by forest-floor spiders. Journal of Arachnology 31:28-39.

Wise, D. H. 1993. Spiders in ecological webs. Cambridge, University Press. 289p. 